\title{
Links Between the Circadian Rhythm, Obesity and the Microbiome
}

\author{
B. RÁCZ ${ }^{1}$, M. DUŠKOVÁ ${ }^{1,2}$, L. STÁRKA ${ }^{1}$, V. HAINER ${ }^{1}$, M. KUNEŠOVÁ ${ }^{1}$ \\ ${ }^{1}$ Institute of Endocrinology, Prague, Czech Republic, ${ }^{2}$ Department of Medicine Strahov, General \\ University Hospital, Prague, Czech Republic
}

Received August 31, 2018

Accepted September 11, 2018

\begin{abstract}
Summary
Obesity is linked to a wide range of serious illnesses. In addition to the important impact on the health of the individual, obesity also has a substantial impact on the economy. Disruption of physiological day-night cycles could contribute to the increased incidence of obesity. According to the American National Sleep Federation, the percentage of the people who reported a sleep duration of six hours or less increased from 12 to $37 \%$ over ten years. Insufficient sleep leads not only to an increase of the total calorie intake but changes the meal preference in favor of palatable foods and meals with high carbohydrate content. A decrease of leptin and increase of ghrelin levels caused by sleep deficiency can also play a role. In addition to the higher caloric intake, the timing of food consumption should be taken into account. The same meal eaten during the night versus the day is associated with increased postprandial glucose and triglyceride levels. The gut microbiome has also been recently understood as an endocrine system, with links between the gut microbiome and circadian rhythm changes possibly influencing increased obesity.
\end{abstract}

\section{Key words}

Sleep disruption • Night workers • Night eating syndrome • Leptin • Ghrelin • Insulin

\section{Corresponding author}

M. Dušková, Institute of Endocrinology, Národní 8, 11694 Prague 1, Czech Republic. E-mail: mduskova@endo.cz

\section{Introduction}

Since 1975 the prevalence of global obesity has almost tripled. According to the WHO, in 2016 more than
1.9 billion adults (39\%) were overweight, and of these 650 million were obese $(13 \%)$. Being overweight or obese are linked to more deaths worldwide (Cappuccio et al. 2010), than being underweight. In addition to the wellknown consequences of overweight and obesity such as cardiovascular diseases (Knutson 2010), they are also associated with other at least as serious health conditions, for instance some types of cancer (e.g. colorectal, prostate, and breast; Vaughn et al. 2018, Kim et al. 2017), type 2 diabetes mellitus (Gan et al. 2015), and musculoskeletal disorders and disabilities.

The circadian system orchestrates metabolism in daily 24-h cycles. Circadian rhythms have been shown to influence obesity, type 2 diabetes and metabolic syndrome development. There are two different circadian systems: one is located in the brain in the suprachiasmatic nucleus (SCN), and the second in peripheral tissues. The molecular machinery that controls circadian activity is expressed in almost all the peripheral tissues, which contain at least a partially self-sustained circadian oscillator. Interestingly, the brain itself possesses its own circadian oscillation. Lesions of the SCN do not reset circadian rhythmicity, but just desynchronize peripheral tissues. There are three main sources of peripheral clock synchronization: direct entrainment by the $\mathrm{SCN}$, entrainment through feeding-fasting rhythms, and body temperature entrainment (Gnocchi and Bruscalupi 2017).

Clock gene oscillations are necessary for many vital functions and for the control of hormonal levels. In mammals the circadian clock localized in the SCN has a period of $24.2-24.5 \mathrm{~h}$, which is synchronized by external factors, especially by visual pathway, to $24.0 \mathrm{~h}$ (the so-called circadian rhythm). Individuals entrain their 
internal clock differently, using not only on exogenous but also endogenous factors, which produce different phenotypes known as chronotypes (Roenneberg 2015). Evolutionary variation in chronotypes, or sleep and wakefulness patterns, gave our ancestors an advantage by helping them to survive the hours of darkness. Rhythms in physiology, cognition and behavior reach their peaks and valleys earlier or later (i.e. morningness vs. eveningness, also called "early birds" and "night owls"). These differences are apparent in the rhythms of sleep and wakefulness, with late chronotypes exhibiting later sleep times, and the ability to extend their sleep into the day (Kerkhof 1985). For the majority of the population, required wake-up times on work days do not coincide with biologically preferred wake-up times (Roenneberg et al. 2012). Moreover, an increasing part of the population works unusual hours. These unusual work schedules have been linked to increased risks for health and safety.

The energy needed by our body and cells varies across the light-dark cycle. The breakdown of carbohydrates, lipids and proteins vary during this twenty four hours cycle. For example, gluconeogenesis occurs during the day time, whereas glycogenolysis peaks during sleep (Doi et al. 2010). Diurnal insulin variation is inversely related to the cortisol rhythm. Insulin secretion rises during nocturnal sleeping, but the serum level of insulin does not correlate with its secretion due to increased clearance during the night. Glucose levels increase during night sleep, with correlation to growth hormone levels (Van Cauter et al. 1991). The loss of this circadian oscillation pattern correlates with obesity in humans, raising the intriguing question of how hormone secretion dynamics affect adipocyte differentiation.

Adipose tissue is a type of connective tissue in which adipocytes predominate. Adipogenesis is stimulated by adipogenic hormones such as corticosteroids and ghrelin. Zahra et al. (2018) showed that the differentiation of preadipocytes to mature adipocytes is stimulated not only by the intensity of hormonal stimuli, but also depends on the oscillation of the stimuli.

Generally, the circadian timing system synchronizes behavioral cycles and anabolic/catabolic processes with environmental cues, generally connected to periods of light/darkness. This biological clock drives metabolic and hormonal pathways, bile acid synthesis and immune/inflammatory processes. Their proper timing with behavioral cycles and environmental cues is necessary for the prevention of obesity, type 2 diabetes and metabolic syndrome (Tarquini and Mazzoccoli 2017).

\section{The disruption of sleep-wake cycles and obesity in shift workers}

According to the National Sleep Foundation of the United States, in 1998 about $12 \%$ of responders reported sleeping for $6 \mathrm{~h}$ or less, but in 2010 this percentage had increased to approximately $37 \%$ (Hirshkowitz et al. 2015). A short sleep duration ( $\leq 6 \mathrm{~h})$ has been associated with a $45 \%$ increased risk of obesity compared with normal sleep duration (Wu et al. 2014). Night or shift workers are typical examples of those with a disruption of the sleep-wake cycle. Shift work is defined as work outside of typical time (6 a.m.-6 p.m.) (McMenamin 2007). Shift workers represent over $20 \%$ of the workers in industrialized countries (Lee et al. 2007, Stevens et al. 2011). Night/shift workers have a higher risk of cardiovascular diseases (Vyas et al. 2012), and higher risks of some types of cancer and type 2 diabetes (Gan et al. 2015, Young et al. 2013). Reducing the sleep duration, quality of sleep and rapid-eye movement sleep affects substrate oxidation, leptin and ghrelin concentrations, sympathetic nervous activity, sleeping metabolic rate, appetite, food reward, hypothalamicpituitary-adrenal (HPA)-axis activity, and enhancing an energy intake (Gonnissen et al. 2013).

The hypothalamus is a region of the brain central to homeostasis. In shift workers, when food is consumed at night the hypothalamus receives contradicting input from the central clock and the systemic circulation. When rats were fed during their normal sleep period, clock gene rhythms were lost in the hypothalamus (Wang et al. 2017). Skene et al. (2018) used a metabolomics approach to investigate circadian rhythm changes in shift workers. They analyzed not only traditional markers of the circadian clock (melatonin, cortisol and period circadian protein homolog 3 (PER3) expression), but also 132 circulating metabolites. While the traditional markers showed a stable phase after night-shift and day-shift schedules, the metabolites showed reversed rhythms, a loss of rhythm or decreased rhythmicity after a nightshift schedule. These findings may explain how a misalignment between internal circadian rhythmicity and externally imposed behavioral schedules in shift workers leads to changes in the timing of metabolite rhythms, which could indicate a disturbed peripheral clock function in the liver, pancreas, and digestive tract 
(Skene et al. 2018).

During sleep, the body is in a fasting state and glycogenolysis in the liver dominates. The same meal eaten during the night causes an amplified glucose and lipid response in comparison to the day (Lund et al. 2001). Shift and night workers have shown a higher concentration of triglycerides and a lower concentration of HDL cholesterol compared to day workers (Karlsson et al. 2003, Nagaya et al. 2002, Petrov et al. 2013). The general preference for eating snacks and fast foods containing sugar at night also plays an important role (Yoshizaki et al. 2018). A meta-analysis from Bonhman et al. (2016) compared the influence of caloric intake during the night in shift workers, and showed no differences in overall calorie intake over $24 \mathrm{~h}$. The higher incidence of obesity and metabolic disorders in shift workers may thus be caused by other factors such as circadian misalignment, meal timing, food choice and the diurnal variation of energy metabolism. Psychological and behavioral changes associated with chronic fatigue can also play an important role in development of obesity (Neckelman et al. 2007).

\section{Insufficient sleep, the circadian rhythm and hormonal changes}

Insufficient sleep leads to an imbalance in the hormones that are involved in the regulation of hungersatiety. A melatonin onset heralds the beginning of biological night, and individuals with high body fat were found to have consumed their calories $1.1 \mathrm{~h}$ closer to this melatonin onset than lean subjects (McHill et al. 2017).

Leptin was the first adipokine to be described, and plays a key role in the regulation of appetite and body weight (leptin suppresses hunger and food intake). Leptin levels in plasma are highly associated with BMI and the degree of adiposity (Janečková 2003). Cortisol and insulin are potent stimulators of leptin expression, while leptin expression is attenuated by beta-adrenergic agonists, cAMP, and thiazolidinediones (Houseknecht et al. 1998). Leptin levels fluctuate according to changes in calorie intake, with a marked decrease during fasting and an increase in overfed and obese states (Dalamaga et al. 2013). Leptin is secreted in a pulsating fashion and also displays a circadian rhythm. Leptin levels also exhibit sexual dimorphism, with women having higher leptin levels than men; leptin synthesis is stimulated by estrogen, and inhibited by testosterone (Park and Ahima 2015). Obese subjects usually have high levels of circulating leptin, and it is considered a proinflammatory adipokine contributing to low-grade chronic inflammation in obesity.

A short sleep duration was shown to cause a significant reduction of leptin levels $(18 \%, \mathrm{p}=0.04)$ and increase of ghrelin levels $(28 \%, \mathrm{p}<0.04)$ in 12 healthy young men (Mullington et al. 2003). The same study reported an increased appetite (by $23 \%, \mathrm{p}=0.01$ ) and increased consumption of calorie-dense meals (33-45\%, $\mathrm{p}=0.02$ ). Other studies have also confirmed the reduction of leptin levels caused by sleep deprivation (Mullington et al. 2003, Taheri et al. 2004). A positive relationship between quality of sleep and leptin levels in obese type 2 diabetes patients has been described (Hirota et al. 2018), with sleep deprivation also causing insulin resistance. According to a meta-analysis of epidemiological studies, the relationships between sleep duration and type 2 diabetes exhibited a U-shape (Gangwisch et al. 2009), meaning that both short and long sleep durations were associated with an increased prevalence and incidence of diabetes. A study from 1999 found lower glucose tolerance in healthy people with a sleep debt than in those fully rested $(p<0.02)$. They also found increased cortisol levels ( $\mathrm{p}=0.0001$ ) (Spiegel et al. 1999). The development of insulin resistance from sleep deprivation is influenced by higher levels of inflammatory factors (IL-1, IL-6, IL-17, and CRP) (Knutson 2013).

Ghrelin is an orexigenic hormone produced in the stomach (Howard et al. 1996) that stimulates food intake and is involved in the regulation of energy homeostasis (Klok et al. 2007). Ghrelin levels rise during fasting and decrease after food intake and have a diurnal profile (Cummings et al. 2001, Racz et al. 2015). In general, obese people have lower ghrelin levels than lean people (Marzullo et al. 2006). Intravenous application of ghrelin can increase glycemia and decrease insulin levels (Broglio et al. 2003). According to one study (Broussard et al. 2015), sleep restriction was associated with an increase in both nocturnal and daytime ghrelin levels under a standardized diet. Postprandial ghrelin levels (after breakfast, lunch and dinner) remained elevated compared to after normal sleep. Wang et al. (2014) considered the possibility that anxiety induced by ghrelin can participate in the development of obesity through the modification of the gut-brain axis. The opposite may also be true: acute stress (for example sleep deprivation) can cause an elevation of ghrelin levels (Kristensson et al. 2006).

Gut hormones can be released in response to 
food intake or follow a circadian or anticipatory pattern of secretion that is independent of nutrient stimulation. Compared to obese rats, lean rats were found to have higher levels of the anorexigenic gut hormones PYY during the light period and GLP1 during the dark period and a higher peak in the light period. Amylin, a synergistic partner to insulin that is cosecreted from pancreatic $\beta$-cells and plays a role in glycemic regulation, mainly effecting in the central nervous systems, was found to be higher in obese animals during the whole light/dark period (Moghadam et al. 2017). Changes of gut hormones under sleep disorders has raised the issue of what role the gut microbiome plays as an additional factor interfering with the hormonal milieu in the gut, as discussed in the chapter below "Gut microbiome and obesity".

Sleep disruption is a stress factor for an organism. Acute sleep deprivation has been associated with increased evening cortisol levels (Leproult et al. 1997). Under chronic sleep deprivation, such hypercortisolemia may result in decreased insulin sensitivity in peripheral tissues. It is well known that elevated glucocorticoid levels (long lasting stress, Cushing's disease, corticotherapy...) lead to an increase of fat mass. Implantation of corticoid pellets in rats led to a total $5 \%$ weight gain (increased epidydimal and inguinal adipose mass, but not subcutaneous) in comparison to a control group (Zahra et al. 2018). The same study described a strong effect on adipose cell differentiation in cases when they applied corticoid pulses lasting longer than physiological pulses. This was explained by the failure to reset PPARG (peroxisome proliferator activated receptor gamma, also known as the glitazone receptor) level back down as durations got longer, increasing the probability that PPARG levels would stay above a certain threshold and cause the cells to continue in their differentiation.

Sleep deprivation can also lead to the disruption of the autonomic nervous system (increased sympathetic activity). This can result in metabolic disruption, and subsequently obesity, insulin resistance and cardiovascular complications (Tobaldini et al. 2014). Both cross-sectional and longitudinal epidemiological studies have clearly demonstrated that prolonged short sleep durations can lead to hypertension and increased salt retention (Gangwisch 2014). The association of short sleep duration with hypertension is stronger in middleaged adults and in women. Insomnia is associated with a $68 \%$ increased incidence of myocardial infarction and an $85 \%$ increase in risk of stroke (Somers et al. 2008). In one experimental model, the circadian rhythm of natriuretic peptide was altered by rotating the light-dark regimen (Herichová et al. 2014).

\section{Night eating syndrome}

Night eating syndrome (NES) is an eating disorder initially described by Albert Stunkard in 1955 (Stunkard et al. 1955), in which the diurnal pattern of food intake is delayed. The essential signs of NES are: not feeling hungry in the morning, overeating in the evening, difficulty falling asleep, waking at night and eating and feeling depressed. The eating pattern in NES leads to obesity and obesity-related comorbidities (Allison et al. 2014). Circadian patterns of leptin, melatonin and cortisol differ in night eaters from those in healthy subjects (Birketvedt et al. 2014). In addition, a reduced response of $\mathrm{ACTH}$ and cortisol to corticoliberin administration has been described in NES patients. Further studies also observed differences in the circadian rhythms of ghrelin, growth hormone and prolactin in patients with NES compared to controls. Dysfunctions in postsynaptic serotonin transmission and reduced nocturnal rise in plasma melatonin observed in patients with NES may cause impaired circadian rhythms and satiety. Selective serotonin reuptake inhibitors and selective melatonin agonists exert beneficial effects on NES and depressive symptoms, and can therefore be used together with psychological therapies for treatment of this disorder (Kucukgoncu et al. 2015).

\section{Gut microbiome and obesity}

Recently, the human organism has begun to be considered a true ecosystem composed of human cells, bacteria, fungi, algae, and viruses. The gastrointestinal tract houses over $10^{14}$ microorganisms (with a weight of about $1-2 \mathrm{~kg}$ ), which is represented by over 1,000 different species of microbes - bacteria, fungi, viruses (Fujimura et al. 2010). The gut microbiome contains 150 times more genes than the whole human genome (Bermon et al. 2015). The physiological "gut flora“ has vital functions in digestion, maintenance of the immune system, and producing vitamins and enzymes (for example vitamin $\mathrm{K}$ and biotin) (Guarner and Malagelada 2003). The gut microbiome starts to develop during the intrauterine period, and reaches its adult-like form in about the 3rd year of life (but changes can occur 
throughout life). The microbiome is influenced not only by the genotype but also by external factors (for example diet including breastfeeding, environmental factors, and medicines as antibiotics). The microbiome acts like an endocrine organ, producing numerous compounds of hormonal nature (Bermon et al. 2015). Alterations in the bacterial community are associated with health impairments, while increased microbiotic diversity improves the metabolic profile and immunological responses (Bermon et al. 2015).

Microbes in the gastrointestinal tract contribute to energy metabolism through the production of short chain fatty acids (SCFAs) through fermentation. The products of fermentation are absorbed and serve as an energy source for the organism. Products such as butyrate, propionate and acetate seem to have a protective role against diet-induced obesity and insulin resistance (Gao et al. 2009, Lin et al. 2010). These processes as well as others have been proposed as one link between obesity and the gut microbiome (Othman et al. 2016).

SCFAs can also act as signaling molecules and activate various pathways, such as the activation of AMP-activated protein kinase (AMPK) in liver and muscle tissues that triggers the activation of key factors involved in cholesterol, lipid, and glucose metabolism: peroxisome proliferator-activated receptorgamma co-activator 1 alpha (PGC-1 $\alpha$ ), peroxisome proliferator-activated receptor gamma (PPAR $\gamma$ ), and liver $\mathrm{X}$ receptors (LXR) (den Besten et al. 2013).

Modification of the microbiome in density and composition could improve metabolic parameters. In an experimental model, microbial transfection to germ-free mice influenced body composition. Positive changes were correlated with invasion of specific members of Bacteroidetes from the lean into obese mice, and was diet-dependent (Ridaura et al. 2013). Probiotics and antibiotics can modify insulin resistance by influencing microbial composition of the gut (Carvalho et al. 2012). A few observations have confirmed a significant increase in the relative abundance of Firmicutes and a higher Firmicutes/Bacteroidetes ratio in overweight and obese persons. One possible explanation for these findings is that Firmicutes are more effective as an energy source than Bacteroidetes, thus promoting more the efficient absorption of calories and subsequent weight gain (Koliada et al. 2017, Sweeney and Morton 2013, Mathur and Barlow 2015, Barlow et al. 2015).

The efficacy of fecal microbiota transplant for the treatment of obesity and obesity-related metabolic disorders in animals and humans has recently been reviewed by Marotz and Zarrinpar (2016).

There is a growing body of evidence about the gut-brain axis. The circadian rhythm and microbiome are capable of influencing and disrupting each other. The microbiome appears to follow daily rhythms influenced by timing of eating and the types of foods consumed, and to exert effects over the circadian rhythms (Mistlberger and Antle 2011). Obese mice as well as humans have different gut microbiota composition compared to lean counterparts (Ley et al. 2005). Sleep fragmentation in mice leads to an increase of food intake and to reversible changes of the microbiota in favor of a highly fermentative group of microbes and a decrease of Lactobacillaceae. In response to these changes, systemic adipose tissue inflammation and altered insulin sensitivity appeared, probably via colonic epithelium barrier disruption (Poroyko et al. 2016). The important role of the interaction of circadian rhythm and diet in their effect on the intestinal microbiome has been described in mice (Voigt et al. 2014). Mice fed a high fat, high sugar diet responded to reversals of the light/dark cycle with altered intestinal microbiota, while mice fed a standard diet had an unaltered microbiota.

An additional factor participating in microbiota and gut crosstalk concurrently influencing circadian rhythms may be bile acids. Bile acids are synthesized from cholesterol and conjugated with taurine or glycine. Upon food intake, bile salts are released into the duodenum and participate in fat digestion and absorption. Gut microbes in the intestinal lumen deconjugate bile salts to yield unconjugated bile acids. Within the ileal enterocytes, unconjugated bile acids influence the amplitude and periodicity of circadian gene expression (Govindarajan et al. 2016).

Even though the exact mechanisms linking the gut microbiome to obesity are far from being well understood, modulation of the gut microbiota holds a tremendous therapeutic potential for treating the growing obesity epidemic, especially when combined with diet and exercise (Razmpoosh et al. 2016). Evaluations of probiotic (lactobacilli and bifidobacteria) effects are dependent of the type of animal models used, and for this reason more clinical studies are needed. A recent study has suggested that for improving metabolic disorders, probiotics need to be administered through prebiotics (Pothuraju and Sharma 2018). 


\section{Daily rhythm modulating agents}

Chronic circadian disruption due to shift work or jet-lag from frequent travel across time zones leads an increased risk of diabetes, cardiovascular disease, and cancer. The development of new pharmaceuticals to treat circadian disorders could thus be helpful (Antoch and Chernov 2009). Many drugs (e.g. clozapine, prazosin and dopamine) can alter the circadian period. Melatonin is an effective chronobiotic agent that can effectively change the phase and amplitude of circadian rhythms, and in rodents has been demonstrated to have cytoprotective properties influencing weight gain and metabolic disturbances (Prunet-Marcassuset et al. 2003, Terrón et al. 2013). In humans, melatonin has been shown to attenuate the metabolic effect of antipsychotic agents, particularly in bipolar disorder (Romo-Nava et al. 2014). Melatonin tablets with prolonged-release (trade-name Circadin) have been approved for the short-term treatment (up to 3 weeks) of primary insomnia (Lemoine and Zisapel 2012). In rodents subjected to jet lag, a preventive effect of L-carnitine on the disorder of lipid metabolism and circadian clock was found (Xie et al. 2017).

The period-shortening compound dehydroepiandrosterone (DHEA) can also affect the circadian rhythm. DHEA is a weak adrenal androgen and one of the principal neuroactive steroids (Stárka et al. 2015), and is available as a dietary supplement in the USA. Dietary administration of DHEA to mice shortened the free-running circadian period and accelerated re-entrainment to advanced light-dark cycles, thereby reducing jet-lag (Tamai et al. 2018). A drug screen also revealed the involvement of tyrosine kinases, ABL1 and ABL2 (Abelson-related gene protein), and the BCR serine/threonine kinase in regulating circadian period. Drug repurposing may thus be a useful approach for identifying new circadian clock modulators and potential therapies for circadian disorders. Serotonin is a well-known as factor modulating food intake. In healthy subjects serum serotonin are at their highest levels early in the morning and $30 \mathrm{~min}$ before a meal. These oscillations can be disrupted by fasting and obesity (Kwon et al. 2018).

In addition to external factors (light-dark cycle), internal (endogenous) and psychobiological (lifestyle) factors also influence the circadian rhythm. Factors like ageing or low physical activity may act as "chronodisruptors", influencing the circadian rhythmicity of hormones such as adrenal and gonadal steroids. It has been proposed that low-intensity chronic physical activity may be an effective strategy for decreasing morning cortisol in subjects with metabolic dysfunctions and cancer (Vitale et al. 2018). Obesity has recently been defined as a chronobiological disease. Unusual or late meal timing can be circadian chronodisruptors, leading to metabolic impairments, so meal timing may be a new potential target in weight control strategies (Beccuti et al. 2017).

Good sleep hygiene, together with a circadian alignment of food intake, regular meal frequencies, and attention to caloric intake may improve sleep abnormalities and tendency to overweight/obesity by preventing overeating; normalizing substrate oxidation, stress, insulin and glucose metabolism including HOMA-IR index, and leptin, GLP-1 (glucagon like peptide 1) concentrations, lipid metabolism, appetite, energy expenditure and substrate oxidation, and normalizing food reward (Gonnissen et al. 2013). Foods are also an important regulator of the circadian clock in peripheral tissues. Controlling of the timing of food consumption and food composition has been termed chrononutrition. The influence of n-3 PUFA (polyunsaturated fatty acids) in relation to the circadian clock was studied in a mouse model. Fish oil and DHA/EPA (docosahexaenoic acid/eicosapentaenoic acid) facilitated a restricted food-induced entrainment of the peripheral clock through insulin secretion and activation of GPR120 (G-protein coupled receptor 120) (Furutani et al. 2015). Meals supplemented with fish oil and/or DHA/EPA may help entrain the peripheral clock in humans as well.

Exposure to endocrine disrupting compounds (EDs) including the pesticide tributylin, commercial flame retardants, and UV filtering chemicals found in sunscreens can perturb circadian clocks in vertebrates. Certain environmental chemicals may thus induce a new obesogenic mechanism of action (Kopp et al. 2017). Endocrine disrupting chemicals can act as hormones in very small amounts and have significant estrogenic activity. EDs can interact with each other, and have antagonistic, additive or even synergistic effects. Like natural steroids, EDs may also influence the microbiome (Lichten 2017, Kolátorová et al. 2018). The combined influences of insufficient sleep and endocrine disrupting chemicals with impact on the microbiome reflect the complex effects of modern society on human health. 


\section{Conclusion}

Obesity is a global concern connected to wide spectrum of health conditions and complications, which can lead to serious impairments of individual health. A positive energy balance and sedentary lifestyle are surely very important factors, but not the exclusive reasons for the increased incidence of obesity worldwide. Sleep deprivation, artificial lighting, and work during nights play at least as important a role in the development of obesity, acting through a wide spectrum of different processes. The relationships between the gut microbiome, circadian rhythm disturbances and endocrine disrupting chemicals, which could lead to weight gain and obesity- related metabolic disorders, are only at beginning to be understood. Influencing our weight through the microbial system of our body is an exciting topic, which will certainly be the focus of much research in the near future.

\section{Conflict of Interest}

There is no conflict of interest.

\section{Acknowledgements}

This work was supported by a project of the Ministry of Health of the Czech Republic - DRO („Institute of Endocrinology” - EÚ00023761 “) and AZV 17-31670A. The authors kindly acknowledge David W. Hardekopf for the proofreading.

\section{References}

ALLISON KC, GOEL N, AHIMA RS: Delayed timing of eating: impact on weight and metabolism. Curr Obes Rep 3: 91-100, 2014.

ANTOCH MP, CHERNOV MV: Pharmacological modulators of the circadian clock as potential therapeutic drugs. Mutat Res 680: 109-115, 2009.

BAHRAMI-NEJAD Z, ZHAO ML, THOLEN S, HUNERDOSSE D, TKACH KE, VAN SCHIE S, CHUNG M, TERUEL MN: A transcriptional circuit filters oscillating circadian hormonal inputs to regulate fat cell differentiation. Cell Metab 27: 854-868, 2018.

BAOTHMAN OA, ZAMZAMI MA, TAHER I, ABUBAKER J, BAOTHMAN M: The role of gut microbiota in the development of obesity and diabetes. Lipids Health Dis 15: 108, 2016.

BARLOW GM, YU A, MATHUR R: Role of the gut microbiome in obesity and diabetes mellitus. Nutr Clin Pract 30: 787-797, 2015.

BECCUTI G, MONAGHEDDU C, EVANGELISTA A, CICCONE G, BROGLIO F, SOLDATI L, BO S: Timing of food intake: sounding the alarm about metabolic impairments? A systematic review. Pharmacol Res 125: 132-141, 2017.

BERMON S, PETRIZ B, KAJÉNIENĖ A, PRESTES J, CASTELL L, FRANCO OL: The microbiota: an exercise immunology perspective. Exerc Immunol Rev 21: 70-79, 2015.

BIRKEVEDT GS, GELIEBTER A, FLORHOLMEN J, GLUCK ME: Neuroendocrine profile in the night eating syndrome. Curr Obes Rep 3: 114-119, 2014.

BONHAM MP, BONNELL EK, HUGGINS CE: Energy intake of shift workers compared to fixed day workers: a systematic review and meta-analysis. Chronobiol Int 33: 1086-1100, 2016.

BROGLIO F, GOTTERO C, BENSO A, PRODAM F, VOLANTE M, DESTEFANIS S, GAUNA C, MUCCIOLI G, PAPOTTI M, VAN DER LELY AJ, GHIGO E: Ghrelin and the endocrine pancreas. Endocrine 22: 19-24, 2003.

BROUSSARD JL, KILKUS JM, DELEBECQUE F, ABRAHAM V, DAY A, WHITMORE HR, TASALI E: Elevated ghrelin predicts food intake during experimental sleep restriction. Obesity 24: 132-138, 2016.

CAPPUCCIO FP, D’ELIA L, STRAZZULLO P, MILLER MA: Sleep duration and all-cause mortality: a systematic review and meta-analysis of prospective studies. Sleep 33: 585-592, 2010.

CARVALHO BM, GUADANGNINI D, TSUKUMO DML, SCHENKA AA, LATUF-FILHO P, VASSALHO J, DIAS JC, KUBOTA LT, CARVALHEIRA JBS, SAAD MJA: Modulation of gut microbiota by antibiotics improves insulin signalling in high-fat fed mice. Diabetologia 55: 2823-2834, 2012.

CUMMINGS DE, PURNELL JQ, FRAYO RS, SCHMIDOVA K, WISSE BE, WEIGLE DS: A preprandial rise in plasma ghrelin levels suggests a role in meal initiation in humans. Diabetes 50: 1714-1719, 2001. 
DALAMAGA M, CHOU SH, SHIELDS K, PAPAGEORGIOU P, POLYZOS SA, MANTZOROS CS: Leptin at the intersection of neuroendocrinology and metabolism: current evidence and therapeutic perspectives. Cell Metab 18: $29-42,2013$.

DEN BESTEN G, VAN EUNEN K, GROEN AK, VENEMA K, REIJNGOUD DJ, BAKKER BM: The role of shortchain fatty acids in the interplay between diet, gut microbiota, and host energy metabolism. $J$ Lipid Res $\mathbf{5 4}$ 2325-2340, 2013.

DOI R, OISHI K, ISHIDA N: CLOCK regulates circadian rhythms of hepatic glycogen synthesis through transcriptional activation of Gys2. J Biol Chem 285: 22114-22121, 2010.

FUJIMURA KE, SLUSHER NA, CABANA MD, LYNCH SV: Role of the gut microbiota in defining human health. Expert Rev Anti Infect Ther 8: 435-454, 2010.

FURUTANI A, IKEDA Y, ITOKAWA M, NAGAHAMA H, OHTSU T, FURUTANI N, KAMAGATA M, YANG ZH, HIRASAWA A, TAHARA Y, SHIBATA S: Fish oil accelerates diet-induced entrainment of the mouse peripheral clock via GPR120. PLoS One 10: e0132472, 2015.

GAO Z, YIN J, ZHANG J, WARD RE, MARTIN RJ, LEFEVRE M, CEFALU WT, YE J: Butyrate improves insulin sensitivity and increases energy expenditure in mice. Diabetes 58: 1509-1517, 2009.

GAN Y, YANG C, TONG X, SUN H, CONG Y, YIN X, LI L, CAO S, DONG X, GONG Y, SHI O, DENG J, BI H, LU Z: Shift work and diabetes mellitus: a meta-analysis of observational studies. Occup Environ Med 72: 72-78, 2015.

GANGWISCH JE: Epidemiological evidence for the links between sleep, circadian rhythms and metabolism. Obes Rev 10: 37-45, 2009.

GANGWISCH JE: A review of evidence for the link between sleep duration and hypertension. Am J Hypertens 27 : 1235-1242, 2014.

GNOCCHI D, BRUSCALUPI G: Circadian rhythms and hormonal homeostasis: pathophysiological implications. Biology (Basel) 6: E10, 2017.

GONNISSEN HK, HULSHOF T, WESTERTERP-PLANTENGA MS: Chronobiology, endocrinology, and energy- and food-reward homeostasis. Obes Rev 14: 405-416, 2013.

GOVINDARAJAN K, MACSHARRY J, CASEY PG, SHANAHAN F, JOYCE SA, GAHAN CG: Unconjugated bile acids influence expression of circadian genes: a potential mechanism for microbe-host crosstalk. PLoS One 11: e0167319, 2016.

GUARNER F, MALAGELADA JR: Gut flora in health and disease. Lancet 361: 512-519, 2003.

HIROTA T, MORIOKA T, YODA K, TOI N, HAYASHI N, MARUO S, YAMAZAKI Y, KURAJOH M, MOTOYAMA K, YAMADA S, SHOJI T, EMOTO M, INABA M: Positive association of plasma leptin with sleep quality in obese type 2 diabetes patients. J Diabetes Investig 9: 1100-1105, 2018.

HIRSHKOWITZ M, WHITON K, ALBERT SM, ALESSI C, BRUNI O, DONCARLOS L, HAZEN N, HERMAN J, KATZ ES, KHEIRANDISH-GOZAL L, NEUBAUER DN, O'DONNELL AE, OHAYON M, PEEVER J, RAWDING R, SACHDEVA RC, SETTERS B, VITIELLO MV, WARE JC, ADAMS HILLARD PJ: National Sleep Foundation's sleep time duration recommendations: methodology and results summary. Sleep Health 1: 40-43, 2015.

HERICHOVÁ I, AMBRUŠOVÁ J, MOLČAN L', VESELÁ A, SVITOK P, ZEMAN M: Different effects of phase advance and delay in rotating light-dark regimens on clock and natriuretic peptide gene expression in the rat heart. Physiol Res 63 (Suppl 4): S573-S584, 2014.

HOUSEKNECHT KL, BAILE CA, MATTERI RL, SPURLOCK ME: The biology of leptin: a review. J Anim Sci 76: 1405-1420, 1998.

HOWARD AD, FEIGHNER SD, CULLY DF, ARENA JP, LIBERATOR PA, ROSENBLUM CI, HAMELIN M, HRENIUK DL, PALYHA OC, ANDERSON J, PARESS PS, DIAZ C, CHOU M, LIU KK, MCKEE KK, PONG SS, CHAUNG LY, ELBRECHT A, DASHKEVICZ M, HEAVENS R, RIGBY M, SIRINATHSINGHJI DJ, DEAN DC, MELILLO DG, PATCHETT AA, NARGUND R, GRIFFIN PR, DEMARTINO JA, GUPTA SK, SCHAEFFER JM, SMITH RG, VAN DER PLODY LH: A receptor in pituitary and hypothalamus that functions in growth hormone release. Science 273: 974-977, 1996.

JANECKOVA R: The role of leptin in human physiology and pathophysiology. Physiol Res 50: 443-459, 2001. 
KOLIADA A, SYZENKO G, MOSEIKO V, BUDOVSKA L, PUCHKOV K, PEREDERIY V, GAVALKO Y, DOROFEYEV A, ROMANENKO M, TKACH S, SINEOK L, LUSHCHAK O, VAISERMAN A: Association between body mass index and Firmicutes/Bacteroidetes ratio in an adult Ukrainian population. BMC Microbiol 17: $120,2017$.

KARLSSON BH, KNUTSSON AK, LINDAHL BO, ALFREDSSON LS: Metabolic disturbances in male workers with rotating three-shift work. Results of the WOLF study. Int Arch Occup Environ Health 76: 424-430, 2003.

KERKHOF GA: Inter-individual differences in the human circadian system: a review. Biol Psychol 20: 83-112, 1985.

KIM KY, LEE E, KIM YJ, KIM J: The association between artificial light at night and prostate cancer in Gwangju City and South Jeolla Province of South Korea. Chronobiol Int 34: 203-211, 2017.

KLOK MD, JAKOBSDOTTIR S, DRENT ML: The role of leptin and ghrelin in the regulation of food intake and body weight in humans: a review. Obes Rev 8: 21-34, 2007.

KNUTSON KL: Sleep duration and cardiometabolic risk: a review of the epidemiologic evidence. Best Pract Res Clin Endocrinol Metab 24: 731-743, 2010.

KNUTSON KL: Sociodemographic and cultural determinants of sleep deficiency: implications for cardiometabolic disease risk. Soc Sci Med 79: 7-15, 2013.

KOLÁTOROVÁ L, LAPČÍK O, STÁRKA L: Phytoestrogens and the intestinal microbiome. Physiol Res 67 (Suppl 3 ): S401-S408, 2018.

KOPP R, MARTÍNEZ IO, LEGRADI J, LEGLER J: Exposure to endocrine disrupting chemicals perturbs lipid metabolism and circadian rhythms. J Environ Sci (China) 62: 133-137, 2017.

KRISTENSSON E, SUNDQVIST M, ASTIN M, MATTSSON H, DORNONVILLE DE LA COUR C, HÅKANSON R, LINDSTRÖM E: Acute psychological stress raises plasma ghrelin in the rat. Regul Pept 134: 114-117, 2006.

KUCUKGONCU S, MIDURA R, TEK C: Optimal management of night eating syndrome: challenges and solutions. Neuropsychiatr Dis Treat 11: 751-760, 2015.

KWON O, YU JH, JEONG E, YOO HJ, KIM MS: Meal-related oscillations in the serum serotonin levels in healthy young men. Clin Endocrinol (Oxf) 88: 549-555, 2018.

LAVIE CJ, DE SCHUTTER A, MILANI RV: Healthy obese versus unhealthy lean: the obesity paradox. Nat Rev Endocrinol 11: 55-62, 2015.

LEE S, MCCANN D, MESSENGER JC: Working Time around the World: Trends in Working Hours, Laws and Policies in a Global Comparative Perspective. Routledge, Geneva, Switzerland, 2007, p. 96-98.

LEMOINE P, ZISAPEL N: Prolonged-release formulation of melatonin (Circadin) for the treatment of insomnia. Expert Opin Pharmacother 13: 895-905, 2012.

LEPROULT R, COPINSCHI G, BUXTON O, VAN CAUTER E: Sleep loss results in an elevation of cortisol levels the next evening. Sleep 20: 865-870, 1997.

LEY RE, BACKHED F, TURNBAUGH P, LOZUPONE CA, KNIGHT RD, GORDON JI: Obesity alters gut microbial ecology. Proc Natl Acad Sci USA 102: 11070-11075, 2005.

LICHTEN E: Are the estrogenic hormonal effects of environmental toxins affecting small intestinal bacterial and microfilaria overgrowth? Med Hypotheses 109: 90-94, 2017.

LIN HV, FRASSETTO A, KOWALIK EJ JR, NAWROCKI AR, LU MM, KOSINSKI JR, HUBERT JA, SZETO D, YAO X, FORREST G, MARSH DJ: Butyrate and propionate protect against diet-induced obesity and regulate gut hormones via free fatty acid receptor 3-independent mechanisms. PLoS One 7: e35240, 2012.

LUND J, ARENDT J, HAMPTON SM, ENGLISH J, MORGAN LM: Postprandial hormone and metabolic responses amongst shift workers in Antarctica. J Endocrinol 171: 557-564, 2001.

MAROTZ CA, ZARINPARR A: Treating obesity and metabolic syndrome with fecal microbiota transplantation. Yale $J$ Biol Med 89: 383-388, 2016.

MARZULLO P, CAUMO A, SAVIA G, VERTI B, WALKER GE, MAESTRINI S, TAGLIAFERRI A, Di BLASIO AM, LIUZZI A: Predictors of postabsorptive ghrelin secretion after intake of different macronutrients. Clin Endocrinol Metab 91: 4124-4130, 2006.

MATHUR R, BARLOW GM: Obesity and the microbiome. Expert Rev Gastroenterol Hepatol 9: 1087-1099, 2015. 
MCHILL AW, PHILLIPS AJ, CZEISLER CA, KEATING L, YEE K, BARGER LK, GARAULET M, SCHEER FA, KLERMAN EB: Later circadian timing of food intake is associated with increased body fat. Am J Clin Nutr 106: 1213-1219, 2017.

MCMENAMIN TM: A time to work: recent trends in shift work and flexible schedules. Mon Labor Rev 130: 3-15, 2007.

MISTLBERGER RE, ANTLE MC: Entrainment of circadian clocks in mammals by arousal and food. Essays Biochem 49: 119-136, 2011.

MOGHADAM AA, MORAN TH, DAILEY MJ: Alterations in circadian and meal-induced gut peptide levels in lean and obese rats. Exp Biol Med (Maywood) 242: 1786-1794, 2017.

MOON H, DALAMAGA M, KIM S, POLYZOS SA, HAMNVIK O, MAGKOS F, PARUTHI J, MANTZOROS CS: Leptin's role in lipodystrophic and nonlipodystrophic insulin-resistant and diabetic individuals. Endocr Rev 34: 377-412, 2013.

MULLINGTON JM, CHAN JL, VAN DONGEN HP, SZUBA MP, SAMARAS J, PRICE NJ, MEIER-EWERT HK, DINGES DF, MANTZOROS CS: Sleep loss reduces diurnal rhythm amplitude of leptin in healthy men. J Neuroendocrinol 15: 851-854, 2003.

NAGAYA, T, YOSHIDA H, TAKAHASHI H, KAWAI M: Markers of insulin resistance in day and shift workers aged 30-59 years. Int Arch Occup Environ Health 75: 562-568, 2002.

PARK HK, AHIMA RS: Physiology of leptin: energy homeostasis, neuroendocrine function and metabolism. Metabolism 64: 24-34, 2015.

PETROV MER, KIM Y, LAUDERDALE D, LEWIS CE, REIS JP, CARNETHON MR, KNUTSON K, GLASSER SJ: Longitudinal associations between objective sleep and lipids: the CARDIA study. Sleep 36: 1587-1595, 2013.

POROYKO VA, CARRERAS A, KHALYFA A, KHALYFA AA, LEONE V, PERIS E, ALMENDROS I, GILELESHILLEL A, QIAO Z, HUBERT N, FARRÉ R, CHANG EB, GOZAL D: Chronic sleep disruption alters gut microbiota, induces systemic and adipose tissue inflammation and insulin resistance in mice. Sci Rep 6: 35405 , 2016.

POTHURAJU R, SHARMA RK: Interplay of gut microbiota, probiotics in obesity: a review. Endocr Metab Immune Disord Drug Targets 18: 212-220, 2018.

PRUNET-MARCASSUS B, DESBAZEILLE M, BROS A, LOUCHE K, DELAGRANGE P, RENARD P, CASTEILLA L, PÉNICAUD L: Melatonin reduces body weight gain in Sprague Dawley rats with diet-induced obesity. Endocrinology 144: 5347-5352, 2003.

RÁCZ B, DUŠKOVÁ M, VONDRA K, ŠRÁMKOVÁ M, STÁRKA L: Daily profiles of steroid hormones and their metabolites related to food intake. Physiol Res 64 (Suppl 2): S219-S226, 2015.

RAZMPOOSH E, JAVADI M, EJTAHED HS, MIRMIRAN P: Probiotics as beneficial agents in the management of diabetes mellitus: a systematic review. Diabetes Metab Res Rev 32: 143-168, 2016.

RIDAURA VK, FAITH JJ, REY FE, CHENG J, DUNCAN AE, KAU AL, GRIFFIN NW, LOMBARD V, HENRISSAT B, BAIN JR, MUELHBAUER MJ, ILKAYEVA O, SEMENKOVICH CF, FUNAJ K, HAVASHI DK, LYLE BJ, MARTINI MC, URSELL LK, CLEMENTE JC, VAN TREUREN W, WALTERS WA, KNOGHT R, NEWGARD CB, HEATH AC, GORDON JI: Gut microbiota from twins discordant for obesity modulate metabolism in mice. Science 341: 1241214, 2013.

ROENNEBERG T: Having trouble typing? What on earth is chronotype? J Biol Rhythms 30: 487-489, 2015.

ROENNEBERG T, ALLEBRANDT KV, MERROW M, VETTER C: Social jetlag and obesity. Curr Biol 22: 939-943, 2012.

ROMO-NAVA F, ALVAREZ-ICAZA GONZÁLEZ D, FRESÁN-ORELLANA A, SARACCO ALVAREZ R, BECERRA-PALARS C, MORENO J, ONTIVEROS URIBE MP, BERLANGA C, HEINZE G, BUIJS RM: Melatonin attenuates antipsychotic metabolic effects: an eight-week randomized, double-blind, parallel-group, placebo-controlled clinical trial. Bipolar Disord 16: 410-421, 2014.

SKENE DJ, SKORNYAKOV E, CHOWDHURY NR, GAJULA RP, MIDDLETON B, SATTERFIELD BC, PORTER KI, VAN DONGEN HPA, GADDAMEEDHI S: Separation of circadian- and behavior-driven metabolite rhythms in humans provides a window on peripheral oscillators and metabolism. Proc Natl Acad Sci USA 115: 7825-7830, 2018. 
SOMERS VK, WHITE DP, AMIN R, ABRAHAM WT, COSTA F, CULEBRAS A, DANIELS S, FLORAS JS, HUNT CE, OLSON LJ, PICKERING TG, RUSSELL R, WOO M, YOUNG T: Sleep apnea and cardiovascular disease: an American Heart Association/American College of Cardiology Foundation Scientific Statement from the American Heart Association Council for High Blood Pressure Research Professional Education Committee, Council on Clinical Cardiology, Stroke Council, and Council on Cardiovascular Nursing. J Am Coll Cardiol 52: 686-717, 2008.

SPIEGEL K, LEPROULT R, VAN CAUTER E: Impact of sleep debt on metabolic and endocrine function. Lancet 354: 1435-1439, 1999.

SPIEGEL K, LEPROULT R, TASALI E, PENEV P, VAN CAUTER E: Sleep curtailment results in decreased leptin levels and increased hunger and appetite. Sleep 26: 174, 2003.

STÁRKA L, DUŠKOVÁ M, HILL M: Dehydroepiandrosterone: a neuroactive steroid. J Steroid Biochem Mol Biol 145: 254-260, 2015.

STEVENS RG, HANSEN J, COSTA G, HAUS E, KAUPPINEN T, ARONSON KJ, CASTAÑO-VINYALS G, DAVIS S, FRINGS-DRESEN MH, FRITSCHI L, KOGEVINAS M, KOGI K, LIE JA, LOWDEN A, PEPLONSKA B, PESCH B, PUKKALA E, SCHERNHAMMER E, TRAVIS RC, VERMEULEN R, ZHENG T, COGLIANO V, STRAIF K: Considerations of circadian impact for defining 'shift work' in cancer studies: IARC Working Group Report. Occup Environ Med 68: 154-162, 2011.

STUNKARD AJ, GRACE WJ, WOLFF HG: The night-eating syndrome: a pattern of food intake among certain obese patients. Am J Med 19: 78-86, 1955.

SWEENEY TE, MORTON JM: The human gut microbiome: a review of the effect of obesity and surgically induced weight loss. JAMA Surg 148: 563-569, 2013.

TARQUINI R, MAZZOCCOLI G: Clock genes, metabolism, and cardiovascular risk. Heart Fail Clin 13: 645-655, 2017.

TERRÓN MP, DELGADO-ADÁMEZ J, PARIENTE JA, BARRIGA C, PAREDES SD, RODRÍGUEZ AB: Melatonin reduces body weight gain and increases nocturnal activity in male Wistar rats. Physiol Behav 118: 8-13, 2013.

TOBALDINI E, PECIS M, MONTANO N: Effects of acute and chronic sleep deprivation on cardiovascular regulation. Arch Ital Biol 152: 103-110, 2014.

VAN CAUTER E, BLACKMAN JD, ROLAND D, SPIRE JP, REFETOFF S, POLONSKY KS: Modulation of glucose regulation and insulin secretion by circadian rhythmicity and sleep. $J$ Clin Invest 88: 934-942, 1991.

VAUGHN CB, FREUDENHEIM JL, NIE J, SUCHESTON-CAMPBELL L, WACTAWSKI-WENDE J, MARIAN C, SHIELDS PG, KALLAKURY BV, TREVISAN M, OCHS-BALCOM HM: Sleep and breast cancer in the Western New York Exposures and Breast Cancer (WEB) Study. J Clin Sleep Med 14: 81-86, 2018.

VITALE JA, LOMBARDI G, WEYDAHL A, BANFI G: Biological rhythms, chronodisruption and chronoenhancement: the role of physical activity as synchronizer in correcting steroids circadian rhythm in metabolic dysfunctions and cancer. Chronobiol Int 28: 1-13, 2018.

VOIGT RM, FORSYTH CB, GREEN SJ, MUTLU E, ENGEN P, VITATERNA MH, TUREK FW, KESHAVARZIAN A: Circadian disorganization alters intestinal microbiota. PLoS One 9: e97500, 2014.

VYAS MV, GARG AX, IANSAVICHUS AV, COSTELLA J, DONNER A, LAUGSAND LE, JANSZKY I, MRKOBRADA M, PARRAGA G, HACKAM DG: Shift work and vascular events: systematic review and meta-analysis. BMJ 345: e4800, 2012.

WANG D, OPPERHUIZEN AL, REZNICK J, TURNER N, SU Y, COONEY GJ, KALSBEEK A: Effects of feeding time on daily rhythms of neuropeptide and clock gene expression in the rat hypothalamus. Brain Res 1671: 93-101, 2017.

WANG L, SONG Y, LI F, LIU Y, MA J, MAO M, WU F, WU Y, LI S, GUAN B, LIU X: Effects of Wen Dan Tang on insomnia-related anxiety and levels of the brain-gut peptide Ghrelin. Neural Regen Res 9: 205-212, 2014.

WU Y, ZHAI L, ZHANG D: Sleep duration and obesity among adults: a meta-analysis of prospective studies. Sleep Med 15: 1456-1462, 2014.

XIE X, GUO A, WU T, HU Q, HUANG L, YAO C, ZHAO B, ZHANG W, CHI B, LU P, ZHAO Z, FU Z: Preventive effect of L-carnitine on the disorder of lipid metabolism and circadian clock of mice subjected to chronic jetlag. Physiol Res 66: 801-810, 2017. 
YOSHIZAKI T, KOMATSU T, TADA Y, HIDA A, KAWANO Y, TOGO F: Association of habitual dietary intake with morningness-eveningness and rotating shift work in Japanese female nurses. Chronobiol Int 35: 392-404, 2018. 